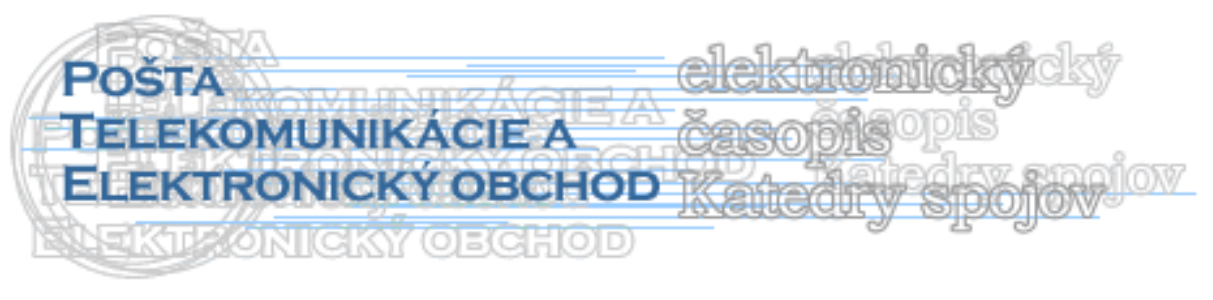

\title{
ŠTANDARD EURÓPSKEHO VÝSKUMU
}

\author{
Anna Pad'ourová, Tatiana Čorejová*
}

\section{Citát}

„Európa musí mat' silný Európsky technologický inštitút, ktorý zjednotí najlepšie mozgy a spoločnosti a bude širit’ výsledky po celej Európe“. José Manuel Barroso - predseda komisie Európskeho technologického inštitútu (EIT), ktorý označil EIT za „nežnú revolúciu pre univerzity".

\section{Úvod}

Jednou z hlavných konkurenčných predností vo vede a technike je množstvo a kvalita l'udských zdrojov. Tento ciel' možno dosiahnut' významnou štrukturalizáciou v rámci organizácie, realizácie a kvality odborného vzdelávania vo výskume, aktívneho kariérneho vývoja výskumných pracovníkov, odovzdávania vedomostí prostredníctvom výskumných pracovníkov medzi sektormi a výskumnými organizáciami a výraznej účasti žien vo výskume a vývoji.

\section{Siedmy rámcový program}

Hlavným nástrojom Európskej únie na financovanie výskumu v Európe je výskum a technologický rozvoj v Siedmom rámcovom programe (7. RP), ktorý sa vzt’ahuje na obdobie rokov 2007 - 2013. Úlohou siedmeho rámcového programu je vzbudit' záujem početnej verejnosti o profesiu výskumného pracovníka a opät' prilákat' popredných perspektívnych odborníkov v oblasti výskumu do Európy.

7. RP obsahuje niekol'ko kl'účových rozdielov oproti predchádzajúcim výskumným programom:

$\checkmark$ Zvýšený rozpočet - rozpočet 7. RP predstavuje pri súčasných cenách nárast o $63 \%$ oproti 6. RP a prináša tak zdroje pre európskych výskum.

$\checkmark$ Zameranie na témy - silný dôraz na hlavné témy výskumu (t. j. zdravie, IKT, vesmír atd'.) - v rámci najrozsiahlejšej časti 7 . RP - Spolupráca - dodáva väčšiu flexibilitu a zvyšuje jeho vnímavost' na potreby priemyslu.

$\checkmark$ Európska rada pre výskum (ERC) - prvá celoeurópska agentúra na financovanie výskumu. Kladie si za ciel' podporovat' rizikovejší, ale prínosnejší európsky výskum.

\footnotetext{
* Ing. Anna Pad’ourová, Katedra spojov, Fakulta Prevádzky a ekonomiky dopravy a spojov, Žilinská univerzita v Žiline, Univerzitná 1, 01026 Žilina, Slovensko

Tel: +421 41 5133129, Fax: +421 41 5655615, e-mail: Anna.Padourova@,fpedas.uniza.sk

Prof. Ing. Tatiana Čorejová, PhD., dekanka FPEDAS, Fakulta Prevádzky a ekonomiky dopravy a spojov, Žilinská univerzita v Žiline, Univerzitná 1, 01026 Žilina, Slovensko Tel: +421 41 5133050, Fax: +421 41 5655615, e-mail: Tatiana.Corejova@,fpedas.uniza.sk
} 
$\checkmark \quad$ Vzdelávanie obyvatel'stva regiónov - 7. RP vytvára nový systém vzdelávania, ktorý spája rôznych partnerov vo výskume v rámci regiónu. Univerzity, výskumné centrá, nadnárodné firmy, miestne úrady a MSP môžu posilnit' svoje schopnosti a potenciál pre výskum.

$\checkmark$ Nástroj na financovanie rozdelenia rizik - slúži na podporu súkromných investorov vo výskumných projektoch a zlepšuje prístup k pôžičkám z Európskej investičnej banky (EIB) pre dlhodobé európske výskumné činnosti.

$\checkmark$ Spoločné technologické iniciatívy (JTIS) - sú určené najmä pre tie činnosti vo výskumnej oblasti, kde sú podpora spolupráce a značné investície nevyhnutné pre dlhodobý úspech. Spájajú rozdielnych partnerov, aby sa pokúsili o dosiahnutie ciel’ov, ktoré nemožno docielit' pomocou „Výziev na predkladanie návrhov““.

$\checkmark$ Jeden helpdesk - „Služba pre otázky o výskume“ - odpovedá na otázky o všetkých stránkach výskumu financovaného EÚ.

Siedmy rámcový program (7. RP) pre výskum a technologický rozvoj venuje mimoriadnu pozornost' Malým a stredným podnikom (MSP) prostredníctvom špecifických programov:

\begin{tabular}{|l|l|}
\hline $\begin{array}{l}\text { Podpora účasti MSP na programe } \\
\text { „Spolupráca“ }\end{array}$ & $\begin{array}{l}\text { MSP sú aktívne vedené k účasti na všetkých } \\
\text { výskumných činnostiach. Vo vhodných } \\
\text { prípadoch sa podporuje účast MSP aj na } \\
\text { spoločných technologických iniciatívach } \\
\text { (JTI). }\end{array}$ \\
\hline Program „Nápady“ & $\begin{array}{l}\text { Rovnako ako akákol'vek iná organizácia } \\
\text { môžu výskumné tímy z MSP konkurovat' } \\
\text { svojou excelentnostou. }\end{array}$ \\
\hline $\begin{array}{l}\text { Ludský potenciál vo výskume a technológii } \\
\text { v programe „Ludia“ }\end{array}$ & $\begin{array}{l}\text { Väčšia pozornost' sa venuje podpore vyššej } \\
\text { účasti MSP v rámci „Partnerstiev a prepojení } \\
\text { medzi priemyselnou a akademickou obcou“ }\end{array}$ \\
\hline $\begin{array}{l}\text { „Výskum v prospech MSP“ v programe } \\
\text { „Kapacity“ }\end{array}$ & $\begin{array}{l}\text { Ciel'om „Výskumu v prospech MSP“ je } \\
\text { posilnit' inovačnú kapacitu európskych MSP } \\
\text { a ich príspevok k rozvoju nových, na } \\
\text { technológiách založených výrobkov a trhov. } \\
\text { Predbežný rozpočet pre osobitné činnosti } \\
\text { MSP predstavuje asi 1,3 mld. EUR. }\end{array}$ \\
\hline
\end{tabular}

Špecifický program Spolupráca (asi 32,2 mld. EUR) - zabezpečuje pomoc pri rozvoji spolupráce medzi priemyslom a vysokoškolskou inteligenciou so zameraním na dosiahnutie vedúcej pozície v hlavných technologických oblastiach. Program Spolupráca je jadrom a zároveň výrazne najväčšou čast'ou 7. RP. Pomáha rozvíjat' spoločný výskum v rámci Európy a iných partnerských krajín, podl'a kl'účových tematických oblastí: zdravie, potraviny, pol'nohospodárstvo a rybolov, biotechnológia, informačné a komunikačné technológie, nanoveda a nanotechnológie, materiály a nové výrobné technológie, energetika, životné prostredie, doprava (vrátane vzdušnej dopravy), socioekonómia a spoločenské vedy, bezpečnost' a vesmír. V tomto programe sú zahrnuté nové spoločné technologické iniciatívy, ktoré vychádzajú z potrieb priemyslu. Ďalšie časti programu zahŕňajú koordináciu výskumných programov mimo Spoločenstva, ktorej hlavnou úlohou je priblížit' európske vnútroštátne a regionálne programy.

$\checkmark$ Špecifický program Myšlienky - Nápady (asi 7,5 mld. EUR) zahrňuje základný výskum, ktorý ma iné pravidlá účasti ako platia v programe Spolupráca. Jediným kritériom schval'ovania takýchto projektov je výnimočnost' vedeckého nápadu. Program Myšlienky 
predstavuje jedinečný flexibilný prístup k európskemu výskumu, v ktorom sa navrhnuté výskumné projekty posudzujú podl'a kvality vyhodnotenej na základe vzájomného profesionálneho preskúmania. Uskutočňuje sa prostredníctvom Európskej rady pre výskum (ERC), ktorá pozostáva z Vedeckej rady (plánovanie vedeckých stratégií, stanovenie pracovného programu, kontrola kvality a informačné aktivity) a implementačného výboru (administrácia, podpora pre žiadatel’ov, kontrola vhodnosti návrhov, riadenie orgánov a praktická organizácia). Výskum možno realizovat' v ktorejkol'vek oblasti vedy. Na rozdiel od programu Spolupráca sa nevyžaduje spolupráca s partnermi z iných krajín.

$\checkmark$ Špecifický program L’udia (asi 4,7 mld. EUR) - je založený na „akciách Maria Curie“, ktoré zahrňujú počiatočné a celoživotné vzdelávanie, výmenu medzi priemyslom a akadémiou a rôzne zvláštne aktivity. Program L'udia poskytuje výraznú podporu pre výskumnú mobilitu a profesionálny rozvoj pre výskumníkov v Európskej únii a mimo nej. Medzinárodné partnerstvo slúži na profesionálny rozvoj výskumníkov realizáciou medzinárodných výmenných pobytov a na spoluprácu s výskumnými skupinami mimo Európy. Uplatňuje sa prostredníctvom súboru akcií s názvom „Marie Curie“ navrhnutého tak, aby výskumníkom pomáhal pri rozvíjaní zručností a schopností v rámci svojich povolaní. Zahŕňa činností ako:

$\checkmark$ úvodné školenie výskumnika,

$\checkmark$ podpora celoživotného vzdelávania,

$\checkmark$ rozvoj prostredníctvom nadnárodných európskych výmenných pobytov,

$\checkmark$ priemyselno-akademické partnerstvá,

$\checkmark$ a iných činností.

$\checkmark$ Špecifický program Kapacity (asi 4,3 mld. EUR) - obsahuje budovanie európskych výskumných infraštruktúr, podporu výskumu, ktorý vychádza v ústrety MSP, podporu regionálnych výskumných zoskupení, vytváranie partnerských programov medzi vedeckovýskumnými inštitúciami v konvergentných regiónoch, študovanie vzt’ahu vedy a spoločnosti, medzinárodnú spoluprácu vo výskume a vývoji pre zapojenie najlepších vedcov z tretích krajín. Program Kapacity slúži na optimálne využitie znalostných kapacít, ktoré Európa potrebuje, ak sa chce stat' prosperujúcou ekonomikou založenou na znalostiach. Posilňovaním výskumných schopností, inovačných kapacít a európskej konkurencieschopnosti tento program stimuluje zdroje znalosti a celý európsky výskumný potenciál. Zahŕňa šest' špecifických oblastí znalostí vrátane:

$\checkmark$ výskumných infraštruktúr,

$\checkmark$ výskumu $v$ prospech malých a stredných podnikov,

$\checkmark$ vzdelávania obyvatel'stva regiónov,

$\checkmark$ výskumného potenciálu,

$\checkmark$ vedy a spoločnosti,

$\checkmark$ činností v rámci medzinárodnej spolupráce.

$\checkmark$ Jadrový výskum (program Euratom) - rozvoj možnosti jadrovej syntézy a štiepenia v rámci Európy. Program Jadrový výskum obsahuje dve časti - prvá sa zameriava na jadrovú syntézu a medzinárodný výskumný projekt ITER, ktorý vznikne v Európe. Projekt ITER je navrhnutý tak, aby sa stal najväčším vedeckým projektom na Zemi. Druhá čast' programu pokrýva činnosti spoločného výskumného centra, ktoré v tejto oblasti zahŕn̆a rozvíjanie pohl'adu na riadenie a uskladňovanie rádioaktívneho odpadu z európskej úrovne, udržiavanie bezpečného chodu jadrových zariadení a podporu d’alšieho výskumu jadrovej energie.

\section{Čo môže výskum a výskumník očakávat' od 7. RP?}

$\checkmark$ výmena vedomostí a skúseností, možnost' medzinárodného porovnania,

$\checkmark$ výmena výskumníkov, nové možnosti vedeckej kariéry,

$\checkmark$ nové skúsenosti s prácou $\mathrm{v}$ medzinárodnom prostredí, 
$\checkmark$ finančné prostriedky pre výskumné ale aj podporné aktivity,

$\checkmark$ podpora rozvoja najlepších myšlienok a l’udí v základnom výskume,

$\checkmark$ podpora individuálnych tímov, zvýšenie výnimočnosti prostredníctvom celoeurópskej sút'aže,

$\checkmark$ zvýšenie vedeckej prestíže pracoviska aj jednotlivcov.

\section{Čo môže priemysel očakávat' od 7. RP?}

$\checkmark$ prístup k novým výsledkom, ktoré vytvárajú novú bázu poznatkov a technológií,

$\checkmark$ nové kontakty užitočné pre nadviazanie obchodných vzt'ahov,

$\checkmark$ rozšírenie finančnej pomoci pre výskumné aktivity a následnú inováciu výrobkov, procesov a služieb,

$\checkmark$ zníženie komerčného rizika pri náročných inovačných projektov,

$\checkmark$ nové medzinárodné kontakty s výskumnými organizáciami.

\section{Literatúra}

[1] www.ec.europa.eu/research/enquiries

[2] www.erc.europa.eu

[3] www.jrc.ec.europa.eu 